\title{
Characterisation of the external surfaces of Pseudomonas aeruginosa isolated from human blood and respiratory tract
}

\author{
H. MISUMI, A. UMEDA*, K. EGUCHI, K. OKADA, Y. SAWAE, Y. NIHO and K. AMAKO* \\ First Department of Internal Medicine and *Department of Bacteriology, Faculty of Medicine, Kyushu University, \\ 3-1-1 Maidashi, Higashi-ku, Fukuoka 812, Japan
}

\begin{abstract}
Summary. The surface structures of the cell envelopes of 16 clinical isolates of Pseudomonas aeruginosa were examined by electronmicroscopy with the new fixation technique of freezesubstitution. Two types of structures were observed among the organisms. In one group of strains, mostly isolated from blood, a dense fibrous layer c. $30 \mathrm{~nm}$ thick was found around the outer-membrane surface, whereas no such structure was observed in the other group of isolates, most of which were from sputum. Lipopolysaccharides extracted from the isolates with a dense fibrous layer were found by SDS-PAGE to have long O-polysaccharide chains, whereas strains without such a layer mostly had lipopolysaccharides that lacked high mol. wt. O-polysaccharide chains.
\end{abstract}

\section{Introduction}

Pseudomonas aeruginosa is a nosocomial pathogen that causes serious infections in compromised patients, especially in those with severe burns or wound injuries and immunological deficiency. In addition, this organism is a major cause of chronic infections in patients with cystic fibrosis. ${ }^{1,2}$ Isolates from patients with cystic fibrosis often produced a mucoid alginate ${ }^{3}$ which may act as a barrier to the interaction of the bacteria with serum factors or phagocytes. ${ }^{4-6}$ In other types of infection it is conceivable that the pseudomonas may have protective barriers other than alginate that contribute to its survival. In particular, long O-polysaccharide chains of the lipopolyosaccharide (LPS) may act as a shield. In this study we compared the length of the O-polysaccharide chains of LPS of isolates from blood and sputum, by electronmicroscopy and chemical methods.

\section{Materials and methods}

\section{Bacterial strains and culture media}

Sixteen clinical strains of $P$. aeruginosa isolated at Kyushu University Hospital were used; eight were from the blood of patients with haematopoietic disorders such as leukaemia and malignant lymphoma, and the other eight were from sputum samples of patients with chronic respiratory tract infections (table). NAC Selection Medium (Eiken Kagaku Co., Ltd, Tokyo, Japan) was used for the isolation of the

Received 27 July 1993; accepted 13 Oct. 1993. organisms. MacConkey agar (Eiken) supplemented with glycerol $5 \%$ was used for the demonstration of mucoid appearance and Brain Heart Infusion (BHI) broth or agar (Eiken) was used routinely for the maintenance or growth of bacteria.

\section{Serotyping}

Bacteria were serotyped according to the typing scheme of the Japanese Pseudomonas aeruginosa Society. The agglutination method was used with a set of 14 O-antisera (Denka Seiken Co., Ltd, Tokyo, Japan).

\section{Electronmicroscopy}

Thin sections of log-phase bacteria were made by freeze-substitution, as described previously. ${ }^{7,8}$ Sections were stained with uranyl acetate and lead citrate and examined with a JEM 2000EX electronmicroscope at $100 \mathrm{kV}$.

\section{Immuno-electronmicroscopy}

Before freeze-fixation, the bacteria were treated with $O$-antisera for the specific serotyping of $P$. aeruginosa, then washed with phosphate-buffered saline (PBS). Subsequently, antibodies that had bound to the bacterial LPS were labelled with protein A-colloidal gold by the method of Frens ${ }^{9}$ and Roth et al. ${ }^{10}$ and processed for electronmicroscopy as described above.

\section{Extraction of LPS}

LPS was extracted from the bacteria by the method of Preston and Penner. ${ }^{11}$ Briefly, cells from a log-phase 
Table. Characterisation of $P$. aeruginosa isolates and relationship between LPS pattern and serum sensitivity

\begin{tabular}{|c|c|c|c|c|}
\hline $\begin{array}{c}\text { Type of } \\
\text { LPS* }\end{array}$ & Serotype $\dagger$ & $\begin{array}{c}\text { Strain } \\
\text { and source§ }\end{array}$ & $\begin{array}{c}\text { Serum } \\
\text { sensitivity }\end{array}$ & $\begin{array}{c}\text { Mucoid } \\
\text { appearance }\end{array}$ \\
\hline \multirow[t]{9}{*}{ Type 1} & $\mathrm{~A}(\mathrm{O} 3)_{+}^{+}$ & B1 & Resistant & - \\
\hline & & B8 & Resistant & - \\
\hline & $\mathrm{B}(\mathrm{O} 2,5,16)$ & B11 & Resistant & - \\
\hline & $\mathrm{E}(\mathrm{O} 9)$ & B5 & Resistant & - \\
\hline & $\mathrm{G}(\mathrm{O} 6)$ & B3 & Resistant & - \\
\hline & & B7 & Resistant & - \\
\hline & & S1 & Resistant & + \\
\hline & & $\mathrm{S} 12$ & Resistant & + \\
\hline & $\mathrm{I}(\mathrm{O} 1)$ & $\mathrm{B} 2$ & Resistant & - \\
\hline \multirow[t]{2}{*}{ Type 2} & M (Homma 15, 17) & $\mathrm{S} 2$ & Sensitive & + \\
\hline & & S3 & Sensitive & - \\
\hline \multirow[t]{4}{*}{ Type 3} & $\mathrm{~B}(\mathrm{O} 2,5,16)$ & S5 & Sensitive & + \\
\hline & $\mathrm{G}(\mathrm{O} 6)$ & S6 & Sensitive & + \\
\hline & & S8 & Sensitive & - \\
\hline & $\mathrm{H}(\mathrm{O} 10)$ & S4 & Sensitive & + \\
\hline \multicolumn{5}{|l|}{ * See fig. 5} \\
\hline \multicolumn{5}{|c|}{$\begin{array}{l}\text { Typing scheme of the Japanese Pseudomonas aeruginosa Society. } \\
\$ \text { ( ); International Antigenic Typing Scheme and Homma serotype corresponding to the } \\
\text { Japanese Typing Scheme. } \\
\S \text { Isolates with prefix B were from blood, those with prefix S were from sputum. }\end{array}$} \\
\hline
\end{tabular}

culture were collected by centrifugation at $1000 \mathrm{~g}$ for 20 min then washed with BHI broth and resuspended in cold physiological saline to give an absorbance of 0.3 at $660 \mathrm{~mm}$. The bacteria were collected by centrifugation from $3 \mathrm{ml}$ of this suspension and resuspended in $400 \mu \mathrm{l}$ of a lytic buffer comprising glycerol $20 \%, 2-$ mercaptoethanol $5 \%$ and sodium dodecyl sulphate $4.6 \%$ in $0.125 \mathrm{M}$ Tris- $\mathrm{HCl}$ buffer, $\mathrm{pH} 6.8$, then heated at $100^{\circ} \mathrm{C}$ for $10 \mathrm{~min}$. Afterwards, the suspension was cooled to room temperature and proteins were digested by adding $40 \mu \mathrm{l}$ of proteinase $\mathrm{K}$ (Wako Junyaku, Tokyo, Japan) $2.5 \mathrm{mg} / \mathrm{ml}$. The mixture was allowed to stand for $60 \mathrm{~min}$ at $60^{\circ} \mathrm{C}$. Finally, the enzyme was inactivated by boiling for $5 \mathrm{~min}$ and the remaining solution was used as a source of LPS for electrophoresis.

\section{Electrophoresis of LPS}

Extracted LPS $(12.5 \mu \mathrm{l})$ was subjected to SDSPAGE on the gel system of Laemmli, ${ }^{12}$ then visualised by silver staining with the method of Tsai et al. ${ }^{13}$

\section{Immunoblotting of LPS with $O$-specific antiserum}

LPS molecules in the SDS-PAGE gels were transferred to nitrocellulose sheets $(0.45 \mu \mathrm{m}$ pore size; Schleicher and Schuell Ltd, Dassel, Germany). The transfer buffer, described previously by Towbin et al., ${ }^{14}$ comprised $25 \mathrm{~mm}$ Tris- $\mathrm{HCl}, 192 \mathrm{~mm}$ glycine and methanol $20 \% \mathrm{v} / \mathrm{v}$. Electrophoresis was continued for $18 \mathrm{~h}$ at $30 \mathrm{~V}$ and $0^{\circ} \mathrm{C}$. After transfer of the proteins, the nitrocellulose sheets were immersed in PBS containing Tween $200.05 \%$ (PBS-Tween) for $20 \mathrm{~min}$ and then in PBS-Tween containing bovine serum albumin (Wako)
$0.05 \%$ for $30 \mathrm{~min}$ to quench non-specific binding of antibody. The sheet was then immersed for $90 \mathrm{~min}$ at room temperature in PBS-Tween containing specific anti-O antisera (Denka) that has been diluted $c$. 50-fold. Afterwards, the sheets were washed with PBSTween and the reactions of the antibody with the LPS were visualised by adding peroxidase-conjugated goat anti-rabbit IgG (Cappel, Cooper Biomedical, Inc., Malverm, USA), used at a dilution of 1 in 750, and its substrate 4-chloro-1-naphthol (Wako) and hydrogen peroxide. Details of the method were as described by Preston and Penner. ${ }^{11}$

\section{Serum bactericidal activity}

Serum from the venous blood of 10 healthy volunteers was separated, pooled and stored at $-70^{\circ} \mathrm{C}$ until required.

To test the serum resistance of the bacteria, equal volumes of the pooled normal human sera (PNHS) and log-phase bacteria $\left(1 \times 10^{8} \mathrm{cfu} / \mathrm{ml}\right)$ were mixed in PBS. After incubation at $37^{\circ} \mathrm{C}$ for $60 \mathrm{~min}, 100-\mu \mathrm{l}$ amounts of the mixtures were serially diluted in PBS and 250- $\mu$ l amounts of the dilutions were spread on BHI agar for colony counts.

\section{Results}

\section{Surface structure of $P$. aeruginosa isolates}

Preparations of the 16 isolates were freeze-fixed and examined by electronmicroscopy. All eight organisms isolated from the blood of patients with haematopoietic disorders exhibited a layer of thin fibres on the outer surface of the outer membrane (figs. 1 and 3a). 


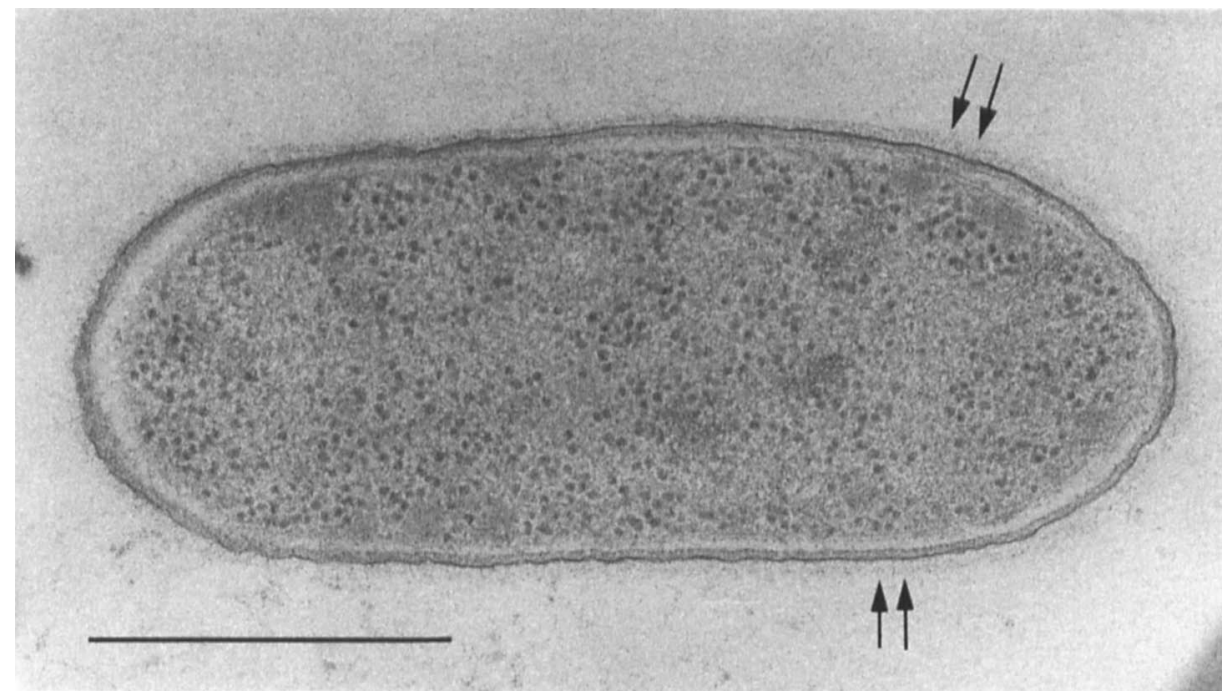

Fig. 1. Electronmicrograph of a cell of strain B8 (serotype A, LPS Type 1), prepared by the freeze substitution method. Arrows indicate the fibrous layer of the outer membrane around the cell. Bar $=500 \mathrm{~nm}$.

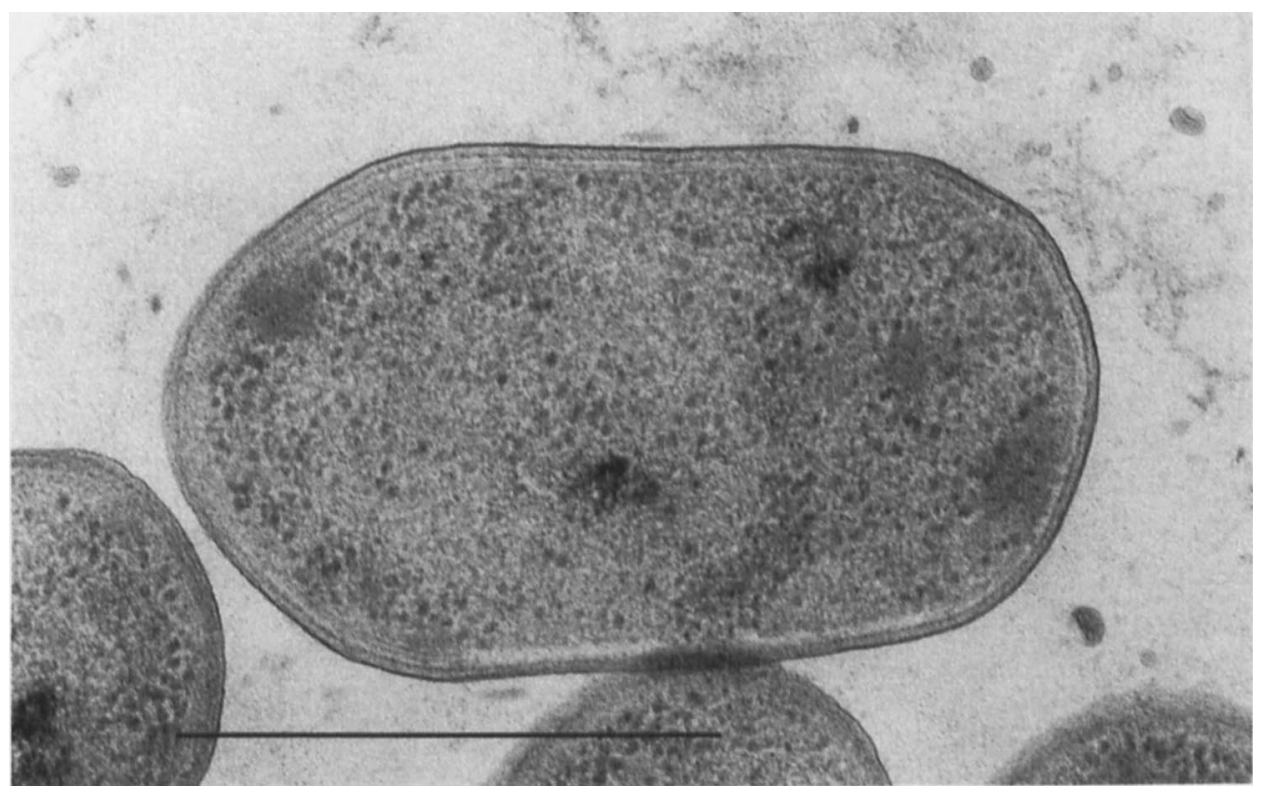

Fig. 2. Electronmicrograph of a cell of strain S3 (serotype M, LPS Type 2) prepared by the freeze-substitution method. Bar = 500 nm.

The thickness of this layer was $c .30 \mathrm{~nm}$. A layer of this type was found in only two of the isolates from the sputum of patients with chronic respiratory tract infection and was absent from the remaining six (figs. $2,3 \mathrm{~b}$ and $3 \mathrm{c})$.

\section{Immuno-electronmicroscopy with anti-O serum}

To ascertain whether the layer detected was the polysaccharide region of LPS or a unique capsular structure, the commercially available anti-O sera to serotypes A (corresponding to $\mathrm{O} 3$ of the International Antigenic Typing Scheme, ${ }^{15}$ IATS) and M (unlisted in IATS; Homma serotype $\left.{ }^{16} 15,17\right)$ were used to label the fibrous layer for immuno-electronmicroscopy. Strains B8 and S3 were tested as these were of serotypes $A$ and $M$, respectively. The reaction sites for the antiserum on the bacterial surface were visualised with a probe of protein A-colloidal gold. As shown in fig. 4a, many colloidal gold particles were found to associate with the fibrous surface layer on the outer membrane of isolate $\mathrm{B} 8$, whereas antiserum for serotype $M$ reacted directly on the outer-membrane surface of strain S3 (fig. 4b). These observations suggested that the fibrous structure comprised the O-polysaccharide chains of LPS, and further experiments aimed to identify the length of this material.

\section{Electrophoretic analysis of LPS from clinical isolates}

Profiles of the molecular size of the LPS from the 16 clinical isolates of $P$. aeruginosa were analysed by SDS-PAGE (fig. 5). Ten isolates showed extensive ladders of high mol. wt O-polysaccharide material (fig. 5, lanes 1-3), whereas two did not show any ladder pattern (lanes 4 and 5) and seemed to be roughtype organisms. The remaining four isolates showed ladders only in the intermediate molecular size range 

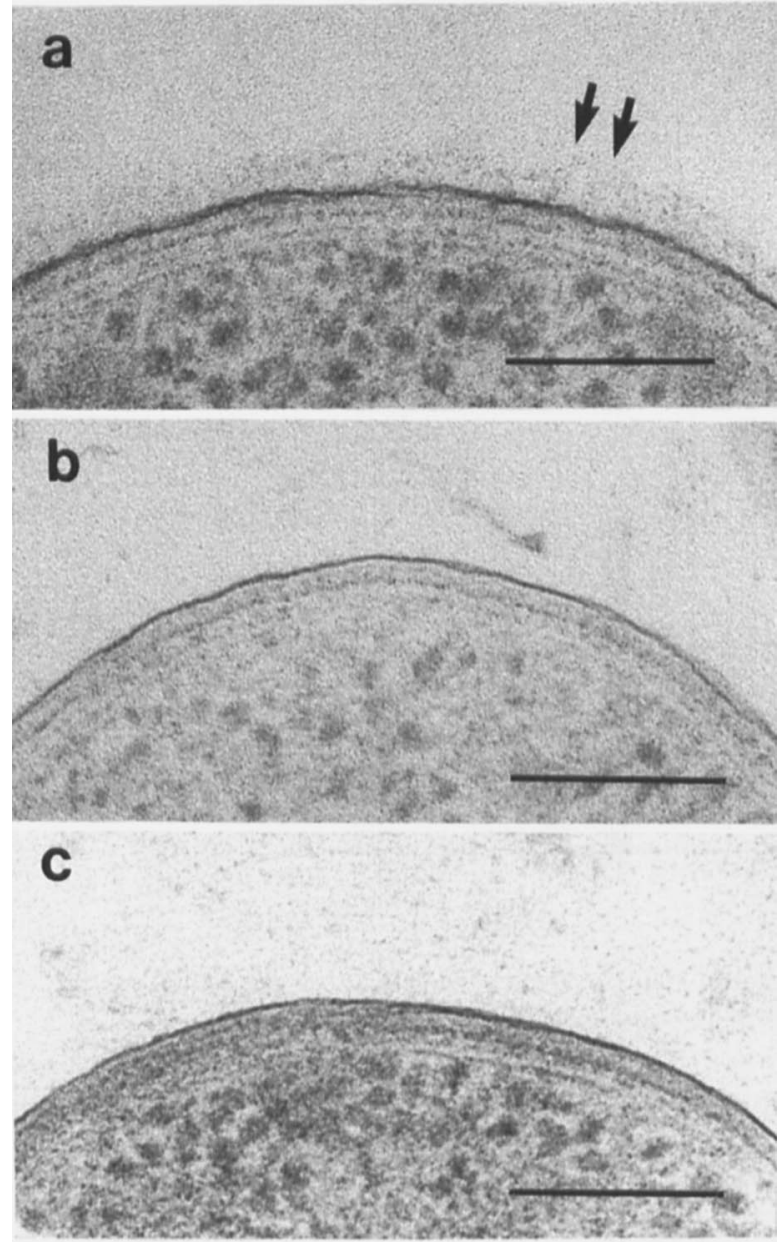

Fig. 3. High magnification view of the surfaces of $P$. aeruginosa cells: a, strain B11 (serotype B, LPS Type 1); b, strain S2 (serotype M, LPS Type 2); c, strain S5 (serotype B, LPS Type 3). Arrows indicate the fibrous layer present in strain B11 and absent from the other organisms. Bars $=100 \mathrm{~nm}$.

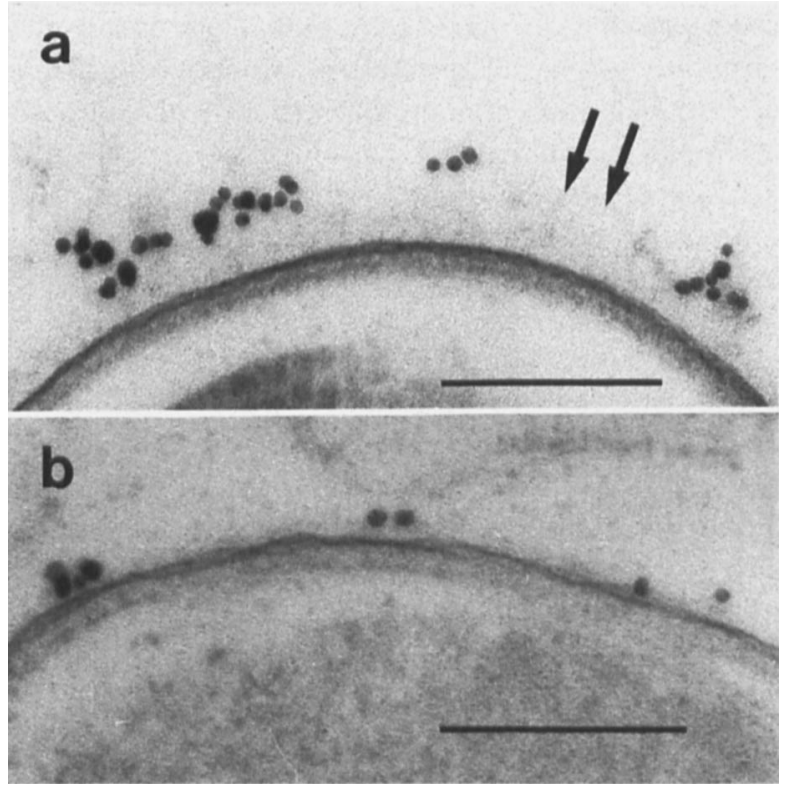

Fig. 4 Immuno-electronmicroscopy of the outer-membrane surface of: a, $P$. aeruginosa B8 (serotype A, LPS Type 1); b, $P$. aeruginosa $\mathrm{S} 3$ (serotype M, LPS Type 2). Note the gold probes attached to the fibrous layer of strain $\mathrm{B} 8$ but directly to the outer-membrane surface of strain S3. Bars $=100 \mathrm{~nm}$.

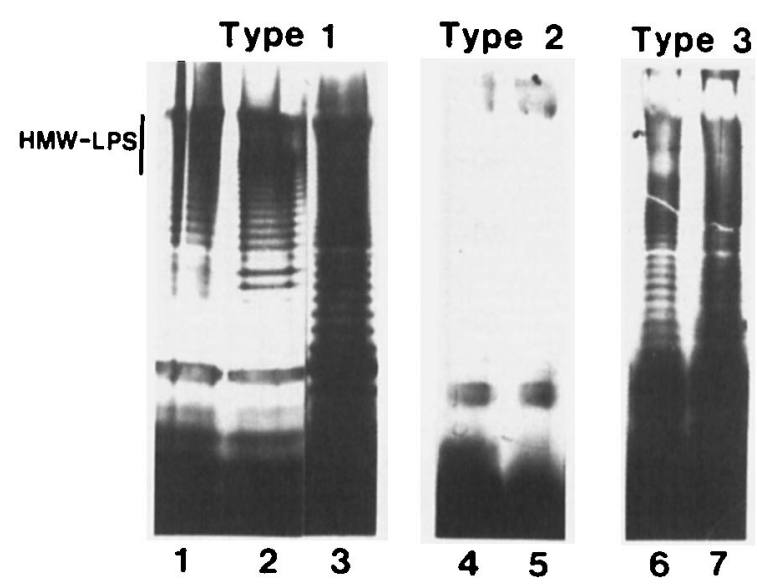

Fig. 5. Electrophoretic profiles of LPS of strains of $P$. aeruginosa. Lane 1, strain B7, serotype G; 2, strain B8, serotype A;3, strain B11, serotype $B ; 4$, strain $S 2$, serotype $M ; 5$, strain $S 3$, serotype $M ; 6$, strain S5, serotype B; 7 , strain S6, serotype G. HMW-LPS: high mol. wt region of LPS.

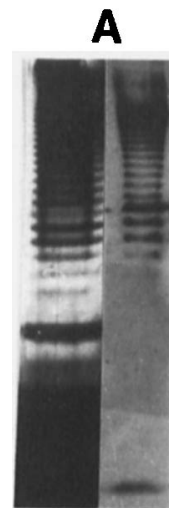

1

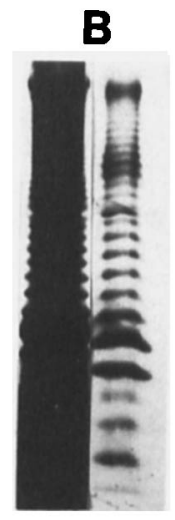

12

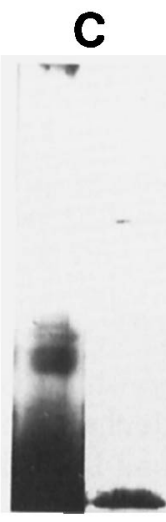

12

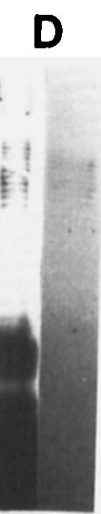

12
Fig. 6. Immunoblotting of electrophoresed LPS with anti-O antisera. Isolates belonging to serotypes A, B and M were selected. Their LPS was electrophoresed and then immunoblotted with anti-A, -B and -M antisera. Lane $\mathbf{1}$ in each zone was silver-stained and lane $\mathbf{2}$ was immunoblotted. A, strain B8 (serotype A, LPS Type 1); b, strain B11 (serotype B, LPS Type 1); C, strain S3 (serotype M, LPS Type 2); D, strain S5 (serotype B, LPS Type 3 ).

(lanes 6 and 7). We termed these three electrophoretic patterns Types 1, 2 and 3, respectively. The relationship between LPS pattern and sources of the bacteria is presented in the table. All the isolates from blood belonged to Type 1 and most respiratory tract isolates belonged to Types 2 and 3 .

\section{Immunoblotting of ladder patterns of LPS with $O$ - antiserum}

To confirm that the ladder pattern seen in SDSPAGE reflected heterogeneity in the size of the Opolysaccharide chains, immunoblots were prepared with anti-O antisera specific to the particular $\mathrm{O}$ serotypes of the isolates (fig. 6). With the Type 1 organisms (fig. 6, panels A and B) the antibodies reacted with ladders in the high mol. wt range. Only rapidly-migrating bands were stained in the LPS from the Type 2 group (panel C) and only the ladder in the intermediate mol. wt range was stained in the LPS from the Type 3 isolates (panel D). 


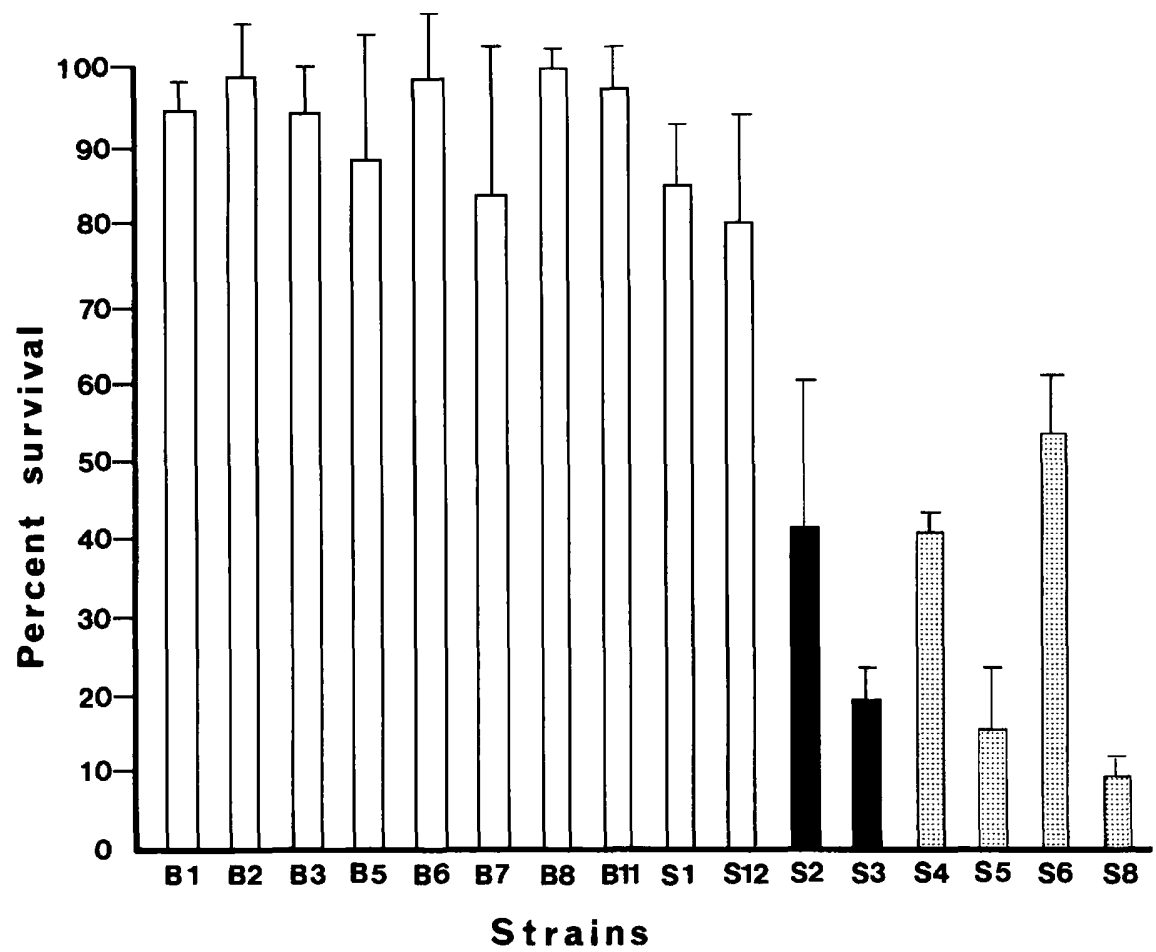

Fig. 7. Serum sensitivity test of the isolates assessed in PNHS, with exposure at $37^{\circ} \mathrm{C}$ for 60 min. The data are sorted according to the LPS profile of the isolates: $\square$ Type 1; $\square$ Type 2; 圆 Type 3. Columns represent mean and bars are SD in two experiments.

\section{Serum sensitivity}

The relationship between the length of $O$ polysaccharide chains of the LPS and serum sensitivity was tested for all 16 strains and results are presented in fig. 7 and the table. Type 1 strains were serum-resistant, whereas organisms belonging to the other two Types were serum-sensitive. Conversely, $\mathrm{O}$-serotype was not related to serum sensitivity, as strains of serotype $B$ (IATS O2, O5, O16) and G (IATS O6) were found in both LPS types (table). In serum bactericidal assays in PNHS $25 \%$ the survival of Type 1 strains averaged nearly $90 \%$ (fig. 7), whereas survival of Type 2 and 3 strains was substantially lower.

\section{Colonial appearance}

None of the blood isolates gave mucoid colonies but most of the sputum isolates did yield such colonies (table).

\section{Discussion}

In this study the fine structures of the outer surfaces of clinical isolates of $P$. aeruginosa were examined by freeze-substitution and by electrophoresis of LPS. Isolates from blood had a fibrous layer on their surface but this was absent from most respiratory tract isolates. Previous authors have claimed that bacteria isolated from blood or the infection source of purulent diseases often have capsular surface layers, ${ }^{17-20}$ and the fibrous structure of our strains superficially appeared much like a capsule. However, the experiments described in this study supported the view that the layer was not a capsule but was composed of long $\mathrm{O}$ polysaccharide chains of the LPS. Evidence for this view came from the observation by immunoelectronmicroscopy that the layer reacted with specific anti O-sera for homologous serotypes, and that the isolates with the fibrous layer gave an extensive ladder pattern in LPS electrophoresis. The size $(30 \mathrm{~nm})$ of the $\mathrm{O}$-polysaccharide chains of $P$. aeruginosa observed in this study is consistent with that observed by Lam et al., ${ }^{21,22}$ but greater than that $(15 \mathrm{~nm})$ observed for Klebsiella pneumoniae. ${ }^{23}$

Most of the $P$. aeruginosa strains isolated from sputum produced mucoid material. Unlike the $\mathrm{O}$ polysaccharide chains, the mucoid material is not firmly anchored on the outer membrane and can be removed easily from the bacterial surface by mechanical washing. In respiratory tract infection the mucoid material may cover the bacteria and act as a barrier to serum killing activity. On the other hand, the blood-stream isolates lacked mucoid material and may have been protected by their long O-polysaccharide LPS chains acting as a barrier to host defence factors.

We thank A. Takade for this help with the electronmicroscopy, K. Hosokawa and T. Koshimizu for their secretarial assistance, and Dr M. L. Robbins for her critical reading of this manuscript. This experiment was supported by a scientific grant from the Takeda Science Foundation and by a Grant-in-Aid for Scientific Research from the Ministry of Education, Science and Culture in 1992. 


\section{References}

1. Doggett RG, Harrison GM, Stillwell RN, Wallis ES. An atypical Pseudomonas aeruginosa associated with cystic fibrosis of the pancreas. J Pediatr 1966; 68: 215-221.

2. Hoiby N, Flensberg EW, Beck B, Briss B, Jacobsen SV, Jacobsen. L. Pseudomonas aeruginosa infection in cystic fibrosis. Diagnostic and prognostic significance of Pseudomonas aeruginosa precipitins determined by crossed immunoelectrophoresis. Scand J Respir Dis 1977; 58: 65-79.

3. Henry RL, Dorman DC, Brown J, Mellis C. Mucoid Pseudomonas aeruginosa in cystic fibrosis. Aust Paediatr $J$ $1982 ; 18: 43-45$.

4. Baltimore RS, Mitchell M. Immunogenic comparison of mucoid strains of $P$. aeruginosa: comparison of susceptibility to opsonic antibody in mucoid and non-mucoid strains. $J$ Infect Dis 1980; 141: 238-247.

5. Goschiniak G, Maresz-Bbczyszyn J, Grzybek-Hryncewiczk K Phagocytosis and intracellular killing of mucoid and nonmucoid variants of Pseudomonas aeruginosa by polymorphonuclear leukocytes: effect of specific immune sera. Arch Immunol Ther Exp 1984; 32: 467-479.

6. Simpson JA, Smith SE, Dean RT. Alginate inhibition of the uptake of Pseudomonas aeruginosa by macrophages. $J$ Gen Microbiol 1988; 134: 29-36.

7. Amako K, Meno Y, Takade A. Fine structures of the capsules of Klebsiella pneumoniae and Escherichia coli K1.J Bacteriol 1988; 170: 4960-4962.

8. Amako K, Murata K, Umeda A. Structures of the envelope of Escherichia coli observed by the rapid-freezing and substitution fixation method. Microbiol Immunol 1983; 27: 95-99.

9. Frens G. Controlled nucleation for the regulation of particle size in monodispersed gold suspension. Nature $1973 ; 241$ : $32-53$.

10. Roth J, Bendayan M, Orci L. Ultrastructural location of intracellular antigens by the use of protein-A gold complex. J Histochem Cytochem 1978; 26: 1074-1081.

11. Preston MA, Penner JL. Structural and antigenic properties of lipopolysaccharides from serotype reference strains of Campylobacter jejuni. Infect Immun 1987; 55: 1806-1812.
12. Laemmli UK. Cleavage of structural proteins during the assembly of the head of bacteriophage T4. Nature 1970; 227: $680-685$.

13. Tsai CM, Boykins R, Gordon CE. Heterogeneity and variation among Neisseria meningitidis lipopolysaccharide. $J$ Bacteriol 1982; 155: 498-504.

14. Towbin H, Staeheim T, Gordon J. Electrophoretic transfer of proteins from polyacrylamide gels to nitrocellulose sheets: procedure and some applications. Proc Natl Acad Sci USA $1979 ; 76$ : 4350-4354.

15. Liu PV, Matsumoto H, Kusuma H, Bergan T. Survey of heat-stable, major somatic antigens of Pseudomonas aeruginosa. Int J Syst Bacteriol 1983; 33: 256-264.

16. Homma JY. A new antigenic scheme and live-cell slideagglutination procedure for the infrasubspecific, serologic classification of Pseudomonas aeruginosa. Jpn J Exp Med 1976; 46: 329-336

17. Cryz SJ, Fuerer E, Germanier R. Experimental Klebsiella pneumoniae burn wound sepsis: role of capsular polysaccharide. Infect Immun 1984; 43: 440-441.

18. Cryz SJ, Fuerer E, Germanier R. Protection against fatal Klebsiella pneumoniae burn wound sepsis passive transfer of anticapsular polysaccharide. Infect Immun 1984; 45: 139-142.

19. Howard CJ, Glynn AA. The virulence for mice of strains of Escherichia coli related to the effects of $\mathbf{K}$ antigens on their resistance to phagocytosis and killing by complement. Immunology 1972; 20: 767-777.

20. Simmons-Smit AM, Verweigh-van Vught JJ. MacLaren DM. The role of $\mathrm{K}$ antigens as virulence factors in Klebsiella. J Med Microbiol 1986; 21: 133-137.

21. Lam JS, Graham LL, Lightfoot T, Dasgupta T, Beveridge TJ. Ultrastructural examination of the lipopolysaccharides of Pseudomonas aeruginosa strains and their isogenic rough mutants by freeze-substitution. $J$ Bacteriol 1992; 174: 7159-7167.

22. Lam JS, Lam MYC, Macdonald LA, Hancock RE. Visualization of Pseudomonas aeruginosa $\mathrm{O}$ antigens by using a protein A-dextran-colloidal gold conjugate with both immunoglobulin $\mathrm{G}$ and immunoglobulin $\mathrm{M}$ monoclonal antibodies. $J$ Bacteriol 1987; 169: 3531-3538.

23. Meno Y, Amako K. Morphological evidence for penetration of anti-O antibody through the capsule of Klebsiella pneumoniae. Infect Immun 1990; 58: 1421-1428. 